deserving to be hanged and quartered in having given us no index for a name-filled, species-filled and fact-filled book.

There are all manner of lovely snippets. I had not known that the first great American ornithologist (Wilson) and the foremost American bird artist (Audubon) both recorded two species that have never been seen by anyone else; or that Audubon left off a title page for Birds of America in order not to have to send nine copies free to British libraries; or that Henry VII had a parrot who called 'Twenty pounds for a boat' after falling into the Thames, but changed, after rescue, to 'Give the knave a groat'. There were many more that caused me to laugh, or be in trigued, or just be fascinated as some previous mystery was explained, but it will take too long to dig them out without that wretched index. However, you will find them sure enough when you read this excellent piece of work.

ANTHONY SMITH

\title{
The Natural History of the Garden, by Michael Chinery. Collins, $£ 4.50$.
}

Thousands of naturalists travel to far places to see plants and animals. How many give a second thought to what lives in their own gardens? This book is a fascinating compendium of information on the wildlife of the garden, lucid and readable, and illustrated with numerous good, of ten excellent, colour plates.

The author takes us down the plant groups from flowering plants through mosses and lichens to fungi, and up through the animal groups from earthworms to mammals. The longest chapter, nearly a third of the book, is devoted to insects, and because there are so many, parts of it read like an annotated catalogue, though it is better on the less well known insect groups. With other invertebrate animals, such as slugs, snails and spiders, the author had more space to devote to their biology and life histories. The book should do a lot to redress the balance of opinion in favour of animals normally regarded as undesirable, such as woodlice, earwigs, millipedes and centipedes.

There are some irritating errors and inconsistencies: the author seems unable to decide whether to use common or Latin names or both; most of the plates have no scale-very misleading when comparing different insects; references to plates in the text are careless, for instance some bees are named in Latin in the text and English in the plate, and unless one knows them already they are difficult to match up.

This is a book to delight naturalists and open their eyes to a world of interest at their own back doors. It is in a long tradition of well informed popular natural history, and will teach many people about creatures they often overlook or even despise. Strongly recommended.

\section{S. R. J. WOODELL}

The World of a Mountain, by William Condry. Faber, $£ 3.50$.

The World of an Island, by Philip Coxon, Faber. $£ 3.25$.

Ponds: their wildlife and upkeep, by Robert Burton. David \& Charles, £3.95.

This splendid introduction to the ecology of British mountains is aimed primarily at young people but could be read with profit and pleasure by adult general readers. The author conducts the reader from the valley through the broad-leaved woodland and conifers of the lower slopes to the grassland zone, past peat-bogs and heather moors to the summit, pointing out the characteristic plants and animals of each zone. He gives a salutary warning of the pressures caused by increasing numbers of walkers and climbers on high level habitats and their wildlife. His final section suggests projects for young people. The author's photographs and Wilhelmina Guymer's line drawings richly enhance the text, and there are lists of helpful books and useful addresses.

The World of an Island deals specifically with North Uist, the 'great bowl of watery desolation', in the Outer Hebrides or Western Isles, where the author was warden of the RSPB's Balranald bird reserve. He describes the geology, climate and wildlife, especially the abundant and varied bird life, with interesting information on the 500 red deer and the grey and common seal populations. The last section is an account of the 
human population-its history, crofting activities and effect on wildlife, especially of the 'machair', the broad belt of fertile grassland running the length of the western side of the island, a unique botanical and zoological habitat now threatened by drainage schemes. Good photographs and attractive drawings by Michèle Coxon.

The Save the Village Pond Campaign has awakened interest in the restoration of our disappearing ponds. Robert Burton devotes most of his book to sections on the physical and chemical aspects of fresh water and the biology of pond animals and plants, with some practical hints on their examination. A short section on the mechanics of pond conservation stresses the necessity of preparing a detailed management plan before starting work. Illustrations consist of photographs by the author's sister, Jane Burton, and line drawings. A few corrections would be desirable in a reprinting, notably the illustration of a community aquarium which includes among its inmates the fiercely carnivorous great diving beetle that would soon be the sole occupant of such a tank, although the text (page 125) rightly suggests keeping predatory creatures for study in isolation.

JOHN CLEGG

Scientific Aspects of Nature Conservation in Great Britain. Royal Society, $£ 3.50$.

British Red Data Book vol 1: Vascular Plants, compiled by F. H. Perring and L. Farrell. Society for the Promotion of Nature Conservation, £2.95.

This hard-backed volume of one issue of the Proceedings of the Royal Society opens with two papers intended to set a philosophical and historical background to nature conservation. J. L. Harley sets out to place nature conservation in Great Britain in a world context and points out that if any land is to remain unexploited, as most conservationists would wish, other land must be exploited to the full. To this extent the interests of the farmer and the conservationist are compatible. But Harley believes conservation to be 'using land wisely' and is not an advocate of wilderness. His definition leaves wisdom undefined, however, and contrasts with his demand that "the work of the ecologist' must have 'no overtones of good or bad or quality judgments'. The question is explored briefly in the discussion. D. A. Ratcliffe, on the other hand, sticks to his brief very closely and considers the work of the Nature Conservancy and its successor the Nature Conservancy Council.

The other papers are perhaps more concerned with the role of the scientist in conservation. J. M. Hellawell discusses the use of various indices of community status which can be used to detect changes, leaning heavily on freshwater examples, while C. D. Pigott contributes a lucid discussion of the ecological information required to formulate conservation plans for threatened habitats and species, a topic also covered by J. P. Dempster. Finally a stimulating paper by A. D. Bradshaw considers a more active side of nature conservation, including methods of restoring damaged land, of creating new and ecologically valuable habitats, and of the introduction and reintroduction of species.

Overall the volume emphasises the dichotomy between the 'wise use of resources' school and those to whom nature conservation revolves around the setting aside of areas in which exploitation for human benefit remains, in the first instance, a low priority. It is as well that this division of opinion is clearly put, for it is very real among natural scientists and others and is often glossed over.

It will be to proponents of the second school that the first of the British Red Data Books will be of greatest interest. It is striking to see endangered plant species accorded the honour of the first issue here. The book gives brief notes on the current status of the 321 rarest plants in Great Britain, which qualify by occurring in fewer than $1510-\mathrm{km}$ squares, and including some unfamiliar, because recently discovered species, such as Galium fleurotii and Ophrys bertolonii. Each is given a somewhat subjective but useful 'threat number', based on features such as number of localities, attractiveness and degree of protection currently enjoyed. This points up both the value and the limitation 